\title{
Canadian science: the golden era
}

from David Spurgeon, Ottawa

IN his final annual report as chairman of the Science Council of Canada, Dr Roger Gaudry looks back to a "golden era" of science policy in 1966, when the council was created, and forward another nine years to the problems of 1984. And in passing he comments on the crises of today, in which "the comfortable academic debate over science policy has largely become a thing of the past for most of us."

The former rector of the University of Montreal, who recently took over as first president of council of the new United Nations University, was the Science Council of Canada's second chairman, after Dr Omond Solandt, the founding chairman. His terms expired this summer.

The "science policy era" had barely begun when the Council was created in 1966, Dr Gaudry recalls. The Glassco Royal Commission Report on Government Organisation was barely three years old, the Senate special committee on science policy had not yet been established, and Canada had not yet been investigated in the OECD series of national science policy studies.

Before 1966, the country's science policy was, in the terminology of the Senate committee report, a "hidden" one. This, said Dr Gaudry, was because the greatest portion of policy work was not close to the point of application and thus was of interest only to the scientific community; most federallysupported science was housed in government laboratories and the universities and was largely self-determined; and because federal funds were largely given without strings, their allocations were not politically important. "Rarely did science or science-related items become public issues," says Gaudry.

By 1966, however, three sets of issues related to science and technology surfaced in public discussions and the press: the controversy over four Big Science projects; arguments over the scale and distribution of growing national research and development expenditures; and discussions over mechanisms for policy formulation and implementation.

The four Big Science projects were: Atomic Energy of Canada Limited's plea for construction of an Intense Neutron Generator (ING), which was opposed by many in the academic engineering community; the withdrawal by the federal Department of Industry of support of McGill University's High Altitude Research Project (HARP); the federal Department of Energy, Mines and Resources' plan to construct the Queen Elizabeth II Telescope in British Columbia, in the face of divided support from astronomers; and the proposal by three (later four) universities in western Canada to build a Tri-university Meson Facility (TRIUMF). The latter was the only one of the four projects destined to be funded to completion.

"Viewed in retrospect," says the Science Council chairman, "the midsixties were a golden era for science and technology, an era of enthusiasm, of rising budgets and of rising hopes. Canada's gross national expenditure on $\mathrm{R} \& \mathrm{D}$ was 15 per cent higher than in 1965 , and that at a time when the annual rate of inflation was about 3.6 per cent."

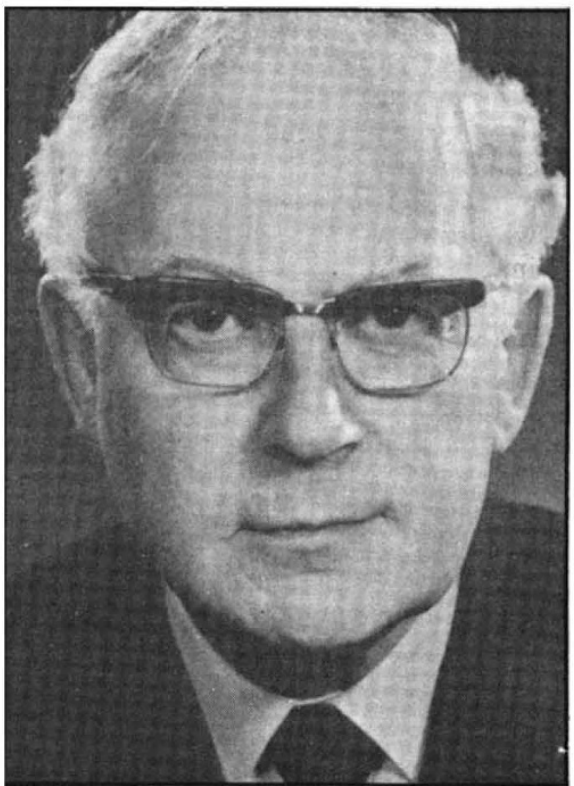

Gaudry: looking back, looking forward

Science policy discussion of the era focused heavily on matters of research per se, as opposed to questions of the uses of science or the effects of technological programs, says Dr Gaudry. Even the Big Science projects had scientific, not technological goals. The participants were drawn almost exclusively from the scientific community itself.

By contrast, "the nature of today's discussion is both more technological and more political in character many of the political issues of today revolve around what technology is, or is not, doing for us." The arguments now surround the James Bay Hydro Project, the Mackenzie Valley Pipeline, the Alberta Oil Sands Project, and the establishment of a second international airport near Toronto, at Pickering, Ont. And these arguments are over the validity of the economic objectives, the environmental impact and the costs, which are expressed in billions rather than millions of dollars.

"The adversaries in these discussions come from all segments of our society rather than from the confines of the scientific community per se. What has changed materially, it seems to me, is the nature of the public's attitude to technological development. Our outlook has matured considerably, we realise that 'bigger' is not necessarily 'better', we have recognised the concept of external costs which can spring as side effects from major projects, and all in all we take a more circumspect view of potential technological changes. What remains to be seen is the extent to which scientific evidence will be given due weight in decision making."

Thus the perception of what science policy is all about has changed since 1966 , as well as the substantive issues. Environmentalism, anti-economic growth thought, economic nationalism, and the emergence of the provinces as significant factors in technological areas, have all come to the fore.

In the background, there has been a small but articulate "anti-science" movement, and demands for technology assessment. Debate concerning industrial strategy has also arisen. And through it all runs the thread of social responsibility, "the growing recognition that our technologies can be made either to serve or to dominate our society."

Looking ahead, Dr Gaudry sees three international problems as important: population growth and inadequate food supplies; resource supply problems due both to depletion and the action of international cartels; the possibility of nuclear proliferation.

He suggests Canada should consider participating in international technological ventures, and says she should avoid being isolated in the face of increasingly organised trade blocs. Domestically, there will have to be some form of national long-range planning in order to solve some problems, such as that of energy supply.

Changes in the structure of the population will have to be coped with, as well as chemical assaults on the environment. Industrial strife may follow technological change if not handled properly, and more public attention may have to be paid to defence technology. And "we will be forced to pay more attention to the concepts of a 'conserver society' and will move away from the maxim that any 'demand' must be satisfied, irrespective of how the demand is generated."

On the technological front, $\mathrm{Dr}$ Gaudry sees growing concern over increasing dependence on systems so large that redundancy in them cannot be afforded. And on the basic research front, the moral and ethical dilemmas of progress in some areas of biology, particularly genetics, will influence policy. 